\title{
Disgust and psychopathological symptoms in a nonclinical sample
}

\author{
Citation for published version (APA):
}

Muris, P. E. H. M., Merckelbach, H. L. G. J., Nederkoorn, C., Rassin, E. G. C., Candel, I. E. L., \&

Horselenberg, R. (2000). Disgust and psychopathological symptoms in a nonclinical sample. Personality and Individual Differences, 29(6), 1163-1167. https://doi.org/10.1016/S0191-8869(99)00263-9

Document status and date:

Published: 01/01/2000

DOI:

10.1016/S0191-8869(99)00263-9

Document Version:

Publisher's PDF, also known as Version of record

\section{Please check the document version of this publication:}

- A submitted manuscript is the version of the article upon submission and before peer-review. There can be important differences between the submitted version and the official published version of record.

People interested in the research are advised to contact the author for the final version of the publication, or visit the DOI to the publisher's website.

- The final author version and the galley proof are versions of the publication after peer review.

- The final published version features the final layout of the paper including the volume, issue and page numbers.

Link to publication

\footnotetext{
General rights rights.

- You may freely distribute the URL identifying the publication in the public portal. please follow below link for the End User Agreement:

www.umlib.nl/taverne-license

Take down policy

If you believe that this document breaches copyright please contact us at:

repository@maastrichtuniversity.nl

providing details and we will investigate your claim.
}

Copyright and moral rights for the publications made accessible in the public portal are retained by the authors and/or other copyright owners and it is a condition of accessing publications that users recognise and abide by the legal requirements associated with these

- Users may download and print one copy of any publication from the public portal for the purpose of private study or research.

- You may not further distribute the material or use it for any profit-making activity or commercial gain

If the publication is distributed under the terms of Article $25 \mathrm{fa}$ of the Dutch Copyright Act, indicated by the "Taverne" license above, 


\title{
Disgust and psychopathological symptoms in a nonclinical sample
}

\author{
Peter Muris ${ }^{\mathrm{a}, *}$, Harald Merckelbach ${ }^{\mathrm{b}}$, Sjaan Nederkoorn $^{\mathrm{b}}$, Eric Rassin ${ }^{\mathrm{b}}$, \\ Ingrid Candel ${ }^{\mathrm{b}}$, Robert Horselenberg ${ }^{\mathrm{b}}$ \\ ${ }^{a}$ Department of Medical, Clinical, and Experimental Psychology, Maastricht University, 6200 MD Maastricht, \\ The Netherlands \\ ${ }^{\mathrm{b}}$ Department of Psychology, Maastricht University 6200 MD Maastricht, The Netherlands
}

Received 26 June 1999; received in revised form 2 November 1999; accepted 13 December 1999

\begin{abstract}
There is little doubt that disgust sensitivity plays a role in the development of small animal phobias. However, it has been suggested that the basic emotion of disgust is implied in a broad range of psychopathological conditions. The present study examined the relationship between disgust sensitivity and symptoms of phobias (other than animal phobias), obsessive-compulsive disorder, depression, and eating disorder in a nonclinical sample. Undergraduate psychology students were asked to complete the Disgust Sensitivity Questionnaire, as well as measures of phobic (Fear Questionnaire), obsessivecompulsive (Maudsley Obsessive-Compulsive Inventory), depressive (Beck Depression Inventory), and eating disorder (Restraint Scale) symptomatology. Results showed that disgust sensitivity was only related to symptoms of agoraphobia and obsessive-compulsive disorder. The present findings cast doubts on the idea that disgust sensitivity is a central factor underlying a broad range of psychopathological conditions. (C) 2000 Elsevier Science Ltd. All rights reserved.
\end{abstract}

Keywords: Disgust; Psychopathological symptoms

\section{Introduction}

Over the past few years, a large body of evidence has accumulated indicating that the basic

\footnotetext{
* Corresponding author. Tel.: + 31-43-3881264; fax: 31-43-3670968.

E-mail address: p.muris@dep.unimaas.nl (P. Muris).
} 
emotion of disgust is involved in the etiology and maintenance of small animal phobias (e.g., spider phobia). Thus, a large number of studies have reported positive relationships between disgust sensitivity and scores on animal phobia questionnaires (e.g., Matchett \& Davey, 1991; Merckelbach, De Jong, Arntz, \& Schouten, 1993; Armfield \& Mattiske, 1996; Mulkens, De Jong, \& Merckelbach, 1996; De Jong, Andrea, \& Muris, 1997). Furthermore, Webb and Davey (1992) showed that disgust may act as a causal antecedent of small animal fears.

In their recent article 'Disgust — the forgotten emotion of psychiatry', Phillips, Senior, Fahy, and David (1998) argue that disgust is a basic emotion that is not only relevant for our understanding of animal phobias, but also for other manifestations of psychopathology. Briefly, Phillips et al. suggest that disgust plays a role in blood-injury phobia and social phobia, obsessive-compulsive disorder, depression, and eating disorders. The present study sought to test Phillips et al.'s suggestion in a nonclinical sample.

\section{Method}

During a large group session, 173 introductory psychology students (42 men and 131 women; mean age: 19.1 years, range 17-28) completed the following questionnaires. (a) The Disgust Sensitivity Questionnaire (DSQ; Rozin, Fallon, \& Mandell, 1984) consists of 24 items, all involving some sort of contamination of otherwise highly desirable food. Subjects have to rate on 9-point scales how much they would like to eat each of the contaminated items. Scores on each item are recorded and summed to yield a total DSQ score ranging between 24 and 216 with higher scores reflecting higher levels of disgust sensitivity. The DSQ is a reliable instrument (e.g., Merckelbach et al., 1993) and there is also evidence that DSQ scores are related to behavioural indices of disgust (Mulkens et al., 1996). (b) The Fear Questionnaire (FQ; Marks \& Mathews, 1979) is a widely used 15-item questionnaire consisting of an agoraphobia, a blood-injury phobia, and a social phobia subscale (range for each subscale: $0=$ not phobic to $40=$ extremely phobic ). A total score can also be obtained by summing the three subscale scores. (c) The Maudsley Obsessive Compulsive Inventory (MOCI; Hodgson \& Rachman, 1977) comprises 30 true-false items that refer to obsessive-compulsive symptoms in four domains: checking, cleaning, doubting, and slowness. A total score can be obtained by summing across all items (range 0-30). (d) The Beck Depression Inventory (BDI; Beck, Rush, Shaw, \& Emery, 1979) is an instrument measuring depressive symptomatology. Subjects have to rate the severity of 21 depressive symptoms on a 4-point scale ranging from $0=$ symptom not present to $3=$ symptom very intense. Total $\mathrm{BDI}$ scores range between 0 and 63 . (e) The Restraint Scale (RS; Herman \& Polivy, 1975) is a 10-item questionnaire measuring attitudes towards weight and eating, frequency of dieting, and weight fluctuations. Each item has to be checked on a 4- or 5-point scale. Total scores vary between 0 and 32, with higher scores reflecting higher levels of eating disorder symptomatology.

\section{Results and discussion}

Internal consistency coefficients (Cronbach's alphas) for the questionnaires that were used in 
the present study were 0.95 for the DSQ, 0.81 for the FQ total phobia score, 0.71 for FQ agoraphobia, 0.73 for FQ blood-injury phobia, 0.66 for FQ social phobia, 0.76 for the MOCI total score, 0.62 for MOCI checking, 0.42 for MOCI cleaning, 0.55 for MOCI doubting, 0.47 for MOCI slowness, 0.81 for the BDI, and 0.81 for the RS. Significant gender differences were found for the DSQ, means being $94.4(S D=37.6)$ for men vs $114.5(S D=32.5)$ for women $[t(171)=3.3, p<0.005]$ and for the RS, means being 6.1 $(S D=3.4)$ for men vs $10.2(S D=$ $5.5)$ for women $[t(113.7$, separate variance estimate $)=-5.7, p<0.001]$. Thus, women displayed higher levels of disgust sensitivity and eating disorder symptomatology than men did.

Table 1 shows correlations (corrected for gender) between disgust sensitivity (DSQ) and selfreport measures of psychopathology. A significant correlation was found between DSQ and FQ total score $(r=0.20, p<0.01)$, indicating that the higher subjects' disgust sensitivity, the higher their level of phobic symptoms. The correlations between DSQ and FQ subscales revealed that FQ agoraphobia in particular was positively connected to disgust sensitivity $(r=$ $0.22, p<0.005)$. At first sight, this connection may seem an unexpected link. Yet, inspection of correlations between disgust sensitivity and separate FQ agoraphobia items revealed that the relation was primarily carried by the items 'traveling by bus or train' $(r=0.22, p<0.005)$, 'walking alone in a crowded street' $(r=0.27, p<0.001)$, and 'traveling far from home on your own' $(r=0.26, p<0.005)$. It is plausible to assume that subjects with high levels of disgust sensitivity prefer their own (clean) home rather than potentially contaminated public places. In passing, it should be noted that the correlation between disgust sensitivity and FQ blood-injury phobia failed to reach significance $(r=0.12)$. Whereas Tolin, Lohr, Sawchuk, and Lee (1997) found evidence that suggest a close connection between disgust and blood-injury phobia, other researchers were unable to replicate this finding (De Jongh, Bongaarts, Vermeule, Visser, De Vos, \& Makkes, 1998; Merckelbach, Muris, De Jong, \& De Jongh, 1999). Thus, the present

Table 1

Mean scores (standard deviations) on various questionnaires and correlations (controlled for gender) between disgust sensitivity (DSQ) and measures of psychopathology

\begin{tabular}{lcc}
\hline & $M(\mathrm{SD})$ & $r$ with DSQ $^{\mathrm{a}}$ \\
\hline DSQ & $109.6(34.8)$ & $0.20^{* *}$ \\
FQ total & $23.1(14.6)$ & $0.22^{* * *}$ \\
FQ agoraphobia & $6.4(5.4)$ & 0.12 \\
FQ blood-injury phobia & $8.4(7.3)$ & 0.15 \\
FQ social phobia & $8.3(5.7)$ & $0.23^{* * *}$ \\
MOCI total & $6.1(4.3)$ & 0.14 \\
MOCI checking & $1.8(1.8)$ & $0.26^{* * *}$ \\
MOCI cleaning & $1.8(1.5)$ & 0.12 \\
MOCI doubting & $1.7(1.5)$ & $0.18^{*}$ \\
MOCI slowness & $1.3(1.3)$ & 0.10 \\
BDI & $6.2(5.4)$ & 0.07 \\
RS & $9.2(5.4)$ & \\
\hline
\end{tabular}

${ }^{\mathrm{a}}$ Note: $\mathrm{DSQ}=$ Disgust Sensitivity Questionnaire, FQ $=$ Fear Questionnaire, $\mathrm{MOCI}=$ Maudsley Obsessive-compulsive Inventory, $\mathrm{BDI}=$ Beck Depression Inventory, $\mathrm{RS}=$ Restraint Scale. $N=173 ;{ }^{*} p<0.05,{ }^{* *} p<0.01,{ }^{* * *} p<$ 0.005 . 
finding favours the conclusion that the relationship between disgust and blood-injury fear is not a robust one.

A positive correlation was also found between disgust sensitivity and MOCI total scores $(r$ $=0.23, p<0.005)$. Further analyses revealed that DSQ was most strongly connected to MOCI cleaning $(r=0.26, p<0.001)$. As expected, subjects with high disgust sensitivity display relatively more compulsive cleaning behaviours.

No significant relationship emerged between DSQ, on the one hand, and BDI and RS, on the other hand ( $r$ s being 0.10 and 0.07 , respectively), suggesting that disgust sensitivity does not contribute to symptoms of depression or eating problems.

\section{Conclusion}

Previous studies have provided firm support for the idea that disgust sensitivity is implied in the etiology of animal phobias (cf. supra). The present study was a first attempt to evaluate Phillips et al.'s (1998) claim that disgust sensitivity plays a role in a wide variety of psychopathological symptoms. Results showed that disgust sensitivity was significantly, and in the expected direction, linked to symptoms of phobia (notably agoraphobia) and obsessivecompulsive disorder (especially cleaning). It should be noted, though, that these correlations were modest (all $r \mathrm{~s}<0.30$ ). Furthermore, no significant relationships were found between disgust and symptoms of depression and eating disorders.

It is important to note that the present study suffered from two important limitations. First of all, disgust sensitivity was assessed by means of the DSQ, a measure that taps only one specific aspect of disgust sensitivity, namely the contamination of highly desirable food items (see supra). Recently, Haidt, McCauley, and Rozin (1994) developed the Disgust Scale which taps seven domains of potential disgust elicitors: food, animals, body products, sex, body envelope violations, death, and hygiene. It is possible that with the employment of this much broader measure of disgust sensitivity, some additional connections between disgust and psychopathological symptoms emerge. Second, the current study relied on a sample of nonclinical subjects who scored relatively low on measures of psychopathology. Thus, it may well be the case that the absence of more clear-cut relations between disgust and psychopathological symptoms was due to a restricted range of scores. In order to clarify this issue, future studies should examine the connection between disgust and psychopathology in subjects with clinical disorders. Meanwhile, as things stand, there is little support for the idea that disgust sensitivity is a factor that is 'central [italics added] to a range of psychiatric phenomena' (Phillips et al., 1998, p. 373).

\section{References}

Armfield, J. M., \& Mattiske, J. C. (1996). Vulnerability representation: the role of perceived dangerousness, uncontrollability, unpredictability, and disgustingness in spider fear. Behaviour Research and Therapy, 35, 899909.

Beck, A. T., Rush, A. J., Shaw, B. F., \& Emery, G. (1979). Cognitive therapy of depression. New York: Guilford. 
De Jong, P. J., Andrea, H., \& Muris, P. (1997). Spider phobia in children: disgust and fear before and after treatment. Behaviour Research and Therapy, 35, 559-562.

De Jongh, A., Bongaarts, G., Vermeule, I., Visser, K., De Vos, P., \& Makkes, P. (1998). Blood-injection-injury phobia and dental phobia. Behaviour Research and Therapy, 36, 971-982.

Haidt, J., McCauley, C., \& Rozin, P. (1994). Individual differences in sensitivity to disgust: A scale sampling seven domains of disgust elicitors. Personality and Individual Differences, 16, 701-713.

Herman, C. P., \& Polivy, J. (1975). Anxiety, restraint, and eating behavior. Journal of Abnormal Psychology, 84, 666-672.

Hodgson, R. J., \& Rachman, S. (1977). Obsessive-compulsive complaints. Behaviour Research and Therapy, 15, 389395.

Marks, I. M., \& Mathews, A. M. (1979). Brief standard self-rating for phobic patients. Behaviour Research and Therapy, 17, 263-267.

Matchett, G., \& Davey, G. C. L. (1991). A test of a disease-avoidance model of animal phobias. Behaviour Research and Therapy, 29, 91-94.

Merckelbach, H., De Jong, P. J., Arntz, A., \& Schouten, E. (1993). The role of evaluative learning and disgust sensitivity in the etiology and treatment of spider phobia. Advances in Behaviour Research and Therapy, 15, 243255.

Merckelbach, H., Muris, P., De Jong, P. J., \& De Jongh, A. (1999). Disgust sensitivity, blood-injection-injury fear, and dental anxiety. Clinical Psychology and Psychotherapy, 6, 279-285.

Mulkens, S., De Jong, P. J., \& Merckelbach, H. (1996). Disgust and spider phobia. Journal of Abnormal Psychology, 105, 464-468.

Phillips, M. L., Senior, C., Fahy, T., \& David, A. S. (1998). Disgust - the forgotten emotion of psychiatry. British Journal of Psychiatry, 172, 373-375.

Rozin, P., Fallon, A. E., \& Mandell, R. (1984). Family resemblance in attitudes to foods. Developmental Psychology, 20, 309-314.

Tolin, D. F., Lohr, J. M., Sawchuk, C. N., \& Lee, T. C. (1997). Disgust and disgust sensitivity in blood-injectioninjury and spider phobia. Behaviour Research and Therapy, 35, 949-953.

Webb, K., \& Davey, G. C. L. (1992). Disgust sensitivity and fear of animals: effect of exposure to violent or revulsive material. Anxiety, Stress, and Coping, 5, 329-335. 